\title{
Research on the Application of E-commerce to Small and Medium Enterprises (SMEs): the Case of India
}

\author{
Assoc. Prof. Nguyen Xuan Trung \\ Vietnam Institute for Indian and Southwest Asian Studies \\ Vietnam Academy of Social Sciences (VASS), Vietnam
}

Dr. Dang Thai Binh

Vietnam Institute for Indian and Southwest Asian Studies

Vietnam Academy of Social Sciences (VASS), Vietnam

E-mail: dangthaibinh1985@gmail.com

Dang Thi Thuy

Thanh Do University, Vietnam

Dong Thi Thuy Linh

Vietnam Institute for Indian and Southwest Asian Studies

Vietnam Academy of Social Sciences (VASS), Vietnam

Received: June 6, 2019 Accepted: June 21, 2019 Published: July 22, 2019

doi:10.5296/ber.v9i3.14893 URL: https://doi.org/10.5296/ber.v9i3.14893

\begin{abstract}
SMEs account for a large propotion and play an important role in the development of each country in the world, including India. The globalization will bring many advantages for enterprises however SMEs will face fierce competition at the local, national and international level. In order to maintain and promote the important role of SMEs in the context of increased competition, SMEs have to change and adopt new technologies. E-commerce and digital technologies are bringing opportunities to help SMEs improve their competitiveness, narrow the gap with big enterprises thanks to their fairness and flexibility of the digital
\end{abstract}


business environment.

According to UNIDO (2017), India is one of the countries successfully applying e-commerce to SMEs. Contributing to this success is the important role of the Indian government. Therefore, this paper focuses on researching the application of e-commerce to SMEs in terms of the role of government in promoting and creating ecosystem for SMEs and e-commerce development.

Keywords: E-commerce, SMEs, Application, India, Benefit

\section{Introduction}

Nowadays, with the development of information technology, it offers a new environment for providing information, sharing knowledge, connecting people, and so on. Moreover, it also provides a new potential market to reach the human being needs. In fact, a few researches (Cohen \& Kallirroi, 2006) have clarified possible shortcomings that smaller businesses can experience due to internet usage. Inpaticular, e-commerce is growing rapidly and becoming a trend of all countries in the world (Sonia Mukherjee, 2017). Therefore, it received much attention of scholars in the world. In particular, scholars focus on the application of e-commerce for SMEs because of the SMEs' role in the economy as well as the great benefits that e-commerce brings to enterprises. In addition, due to the characteristics of SMEs such as small scale, low capital, low technology, labor with low skill, low competitiveness, etc. Therefore, the application of e-commerce for SMEs is an issue that needs to be researched in various aspects.

In India, $27 \%$ of SMEs use e-commerce daily, which can reduce marketing and distribution costs by $60 \%$, and SMEs can use e-commerce with a small investment of around $\$ 100$ (UNIDO (2017). The role of Indian SMEs is recognized by the government, associations and e-commmerce player. The development of SMEs and e-commerce in India is supported by many different entities in which government plays a crucial role. Therefore, research on the application of e-commerce to SMEs from the perspective of the government is not only meaningful to India but also means to other countries in the world.

\section{Literature Review}

\subsection{The Benefits and Effects that E-commerce brings to SMEs}

Nowadays, the development of information technology, especially the industrial revolution 4.0 has created a broad environment and space to provide information, share knowledge, connect people, etc. Moreover, it provides a new potential market to meet human needs. E-commerce provides a variety of information including product-related information, prices, designs, and other utilities. In addition, e-commerce brings many advantages for SMEs such as production expense reduction, management costs reduction and time reduction (Rahayu \& Day, 2015; Dai, Nguyen; Binh, 2017). Indeed, e-commerce provides direct links with customers, vendors, and distributors to facilitate business through the convenient information transfer (Kaynak, Tatoglu, \& Kula, 2005).

Internet and e-commerce are increasingly spreading and bringing countries into a global 
network economy (Gibbs \& Kraemer, 2004). There are many benefits of e-commerce for SMEs (Oye, D Mazleena, S. Noorminshah, 2012; Franco \& Bulomine, 2016), as follows:

Flexible time and place: Based on the Internet, e-commerce can provide on-demand information to users whenever and wherever they are. Businesses can keep their valuable customers longer because they can build a good relationship with them through customer gratitude.

Time saving: Due to the use of virtual environments and the enhancement of visual information, the time to obtain information is significantly reduced compared to traditional methods. Employees spend less time on training and employers spend less time and money on upgrading new technologies and knowledge for employees. E-commerce also reduces the distance between companies and customers. For example, customers can buy, pay, and respond to online products anytime and anywhere.

Shorten the distance between the company and the customer: e-commerce provides direct links among customers, suppliers and distributors as well as facilitates transactions and information transfer. It allows companies to offer new products to new customers or gratitude activities to existing customers. In addition, e-commerce brings opportunity for enterprises to trade their products worldwide without contacting the customer directly or advertising elsewhere in the world (Holley \& Hunton, 1996). Moreover, e-commerce brings many benefits for employers and managers to serve customers more effectively. As a result, e-commerce makes it easy for customers to connect directly with companies through online resources. For example, people can use multimedia devices such as laptops, computers, mobile devices, and iPad to access websites with high speed internet connection and get information about products, prices fast and simply.

Enhanced supply chain: E-commerce can improve supply chain efficiency by providing full information on product usability, inventory levels, shipment status and production requirements (Radstaak, Ben G \& Ketelaar, Mark H \& Hastings, 1998). The study indicates that e-commerce is the best choice not only for big companies or organizations but also for SMEs to improve their connections with customers.

Promote SMEs to participate in the global economy: E-commerce can help SMEs get involved in the global economy by reducing costs and increasing efficiency in information searching, communication and global marketing. In particular, e-commerce can be cross-border implemented, providing opportunities for SMEs to engage in international trade and global economic processes. Meanwhile, good and effective implementation of online transactions creates prestige for SMEs in the international market and helps SMEs to grow stronger (UNIDO, 2018).

Facilitates SMEs growth and creates jobs through innovation of business models: Through e-commerce, SMEs can build a marketing system, implement business strategies, strengthen inter-sectoral cooperation in the global, and thereby enhance global competitiveness. In particularly, for SMEs, e-commerce not only breaks down scale barriers and difficulty in market access but also offers opportunities for cooperation with companies around the world 
and gets more information about the needs of the global market. The business to business (B2B) model provides opportunity for suppliers from developing countries to enter the global market and supply chain. For example, India's largest B2B e-market (IndiaMart.com) mainly provides services to SMEs. Alibaba.com, one of the largest B2B e-commerce in the world, serves over 100 million global SMEs. It includes one million domestic suppliers, 25,000 overseas suppliers, 10 million national costumers and 100 million overseas costumers. The development of business to customer (B2C) e-commerce not only contributes to the development of SMEs, but also directly affects the growth of employment. Currently, JD, one of the largest B2C platforms in China, provides services to over a million small enterprises and directly or indirectly generates more than four million employments. The number of employments generated by Taobao and Tmail is estimated at about 11 million. Especially, the development of $\mathrm{B} 2 \mathrm{C}$ e-commerce has strongly promoted the development of the business inspiration and employment of women. For example, in the online store of Taobao.com, 49\% of shop owners are women (UNIDO, 2018).

Innovation is recognized as an essential component of economic growth and, in this context, it can be broadly defined as the development, deployment and effective use of products, procedure and new services (OECD, 2001; Brem, 2008). As the world economy becomes integrated and interdependent, the ability of entrepreneurs and enterprises to capture global business opportunities by commercializing new products and processes faster than their competitors is very important for a country's economic development (OECD, 2004). SMEs form a very heterogeneous group, consisting of different enterprises types such as grocery stores, restaurants, small computer shops and computer software enterprises. SMEs are dynamic, creative and growth oriented. They are often considered as flexible, creative and adaptive enterprises, and these characteristics, in turn, make them suitable for e-commerce (Al-Qirim, 2007). According to the OECD (2000), e-commerce has the potential to lead to significant productivity gains at the enterprise level. Through e-commerce applications, companies in the supply chain and distribution that previously were not connected could establish direct contact. Zhu and Kraemer (2002) suggest that e-commerce improves information flow and reduces inefficient costs and transaction costs.

\subsection{SMEs' Barriers in Applying E-commerce}

For Vietnamese SMEs, Huu Phuoc Dai Nguyen \& Thai Binh Dang (2017) pointed out some main barriers in applying e-commerce such as technical difficulties when using e-commerce websites, people who is responsible for the service and payment when using e-commerce, the reliability of the service, poor Internet service and information security and the privacy of the customer. In particular, the technical difficulty is the biggest barrier because SMEs may feel their employees is not suitable for applying e-commerce. In addition, many SMEs in Vietnam have no experience in applying e-commerce in their business. Moreovers, SMEs faced other difficulties such as language difficulties, high user support cost, lack of knowledge about e-commerce, issues related to registration and certification and the cost of operating and maintaining the e-commerce system is higher than expectation. According to Thuy Nguyen Xuan (2016), information security is the biggest barrier in the development of e-commerce in Vietnamese SMEs. 


\section{Mll Macrothink}

Business and Economic Research

ISSN 2162-4860

2019, Vol. 9, No. 3

EU companies have also faced a number of e-commerce barriers such as language difficulty, logistical problems related to the interoperability of postal and payment systems and legal barriers to consumers and enterprises (Meglena Kuneva, 2009). Huang (2007) focuses on the e-commerce market in Taiwan. According to these results, the legal system is the most important barrier, followed by the payment system and infrastructure for SMEs. Another study which is conducted in Australia on barriers to SMEs identified eight main barriers to them (Rosemary S. and Standing, 2004). This study classifies barriers into external barriers and internal barriers. External barriers include the lack of a common technology standard, the level of e-competencies within industry sectors, and lack of understanding of the SMEs' needs. Internal barriers include understanding the e-commerce environment, identification benefits, global trading, financial constraints, and supply chain integration. These two studies were limited in sample size, empirical data and the number of barriers examined. In addition, most barriers given were before market entry barriers

In the study conducted by a group of small entrepreneurs in Sweden, Sultana et al. (2011) identified that security issues related to e-commerce was one of the major obstacles in e-commerce implementation. In contrast, Arendt (2008) argues that the most important barrier to e-commerce adoption is insufficient awarenes, knowledge and skills in the company, which is even more important than finance.

Many studies on e-commerce in developed countries show that the problems that SMEs face in developed countries may be quite different from those of SMEs in developing countries (Kapurubandara and Lawson, 2006). Specific challenges for SMEs in developing countries often include the lack of telecommunication infrastructure (poor Internet connectivity), the cost of equipment and services, the lack of qualified staff to for ecommerce development, underdeveloped payment systems, lack of reliable delivery systems, and challenges related consumer such as the lack of skills needed by consumers to use Internet, low income, and high Internet access costs (Almousa, 2013; Kapurubandara and Lawson, 2006). Kshetri (2007) also analyzes e-commerce barriers in developing countries and he found that the most important barriers are low credit card penetration, lack of purchasing power, inadequate legal protection, Low levels of computer skills and English proficiency, lack of availability of local language websites, lack of awareness and knowledge of e-commerce benefits, underdeveloped financial systems, lack of workforce with e-commerce expertise, lack of knowledge to use ICT profitably, etc.

\subsection{Factors Affecting the Success of Applying E-commerce in SMEs}

Along with research on e-commerce barriers, many scholars have paid much attention to the factors affecting the success of e-commerce. Scholars have identified key factors that bring success that are the ability to maintain personal contact while using a business website; web localization to accommodate local customers (cultural appropriateness, local regulations, language, etc.); relationships development between customers or organizations related to $\mathrm{B} 2 \mathrm{~B}$; focus on processes that improve convenience, information, intermediation and price; having the site found near the top of the search results; website development to meet technological change, etc. 


\section{$\triangle$ Macrothink}

Business and Economic Research

ISSN 2162-4860

2019, Vol. 9, No. 3

Gattiker, Perlusz and Bohmann (2000) discuss the importance of global economic and cultural factors in the application of e-commerce of SMEs. Global economic factors include connection costs and the amount of money they spend for online shopping. Global cultural factors include differences in working habits and language. Displaying information about products, services in accordance with local culture and language will promote e-commerce application of SMEs effectively. In addition, Mayer-Guell (2001) discusses the importance of organization's culture that implements eCommerce strategies and finds that eCommerce initiatives will not maximize their potential and effectiveness if employees of the organization can not adapt and respond to changes in the process caused by e-commerce.

Sairamesh et al. (2002) and Freeman et al. (2001) discuss the importance of contracts in the process of applying e-commerce. In the process of e-commerce deployments, SMEs will deal with contractual issues and other legal risks, including intellectual property rights, conflict and dispute resolution, contract performance, patents, trademark and copyright issues. To avoid these risks, enterprises should have legal knowledge and advice on issues related to e-commerce activities of enterprises. This is also one of the factors that determine the success of e-commerce in SMEs.

In order to succeed in applying e-commerce, Castelluccio (2000) pointed out some key factors that determine the success of an enterprise: the business process needs to be completed, systematic maintenance of account information and relationship records, have a good website, use beautiful graphics, have a lot of communication activities, supervise the delivery and receiving good process well, provide useful and continuous web content, provide international services and multi-channel integration. In addition, this study mentioned a number of issues that reduce the success of eCommerce application. These include dead links on web, inaccessible help/call centers, problems related to phishing on the net.

Developing strategies for applying and marketing e-commerce technologies and services requires enterprises to make significant investments. Initial and ongoing investment decisions depend on the perception of the enterprises that future benefits will outweigh the involved cost. Mitra and Chaya (1996) suggest that it is needed to quantify the benefits of investing in e-commerce systems and building a quality e-commerce system will require solid evidence of value added to customers. Value added for customers will bring additional profit to the enterprises because they can maintain existing customer relationships and develop new relationships based on attractive services

\section{E-commerce Application in India}

SMEs are considered the "backbone" of the Indian economy and are acknowledged for their importance by governments, associations, e-commerce businesses (Girish S. Bagale, Pooja Sharma, 2014). Thus, with the participation of these components, it creates an ecosystem to help SMEs and e-commerce develop in parallel (KPMG, 2016). 


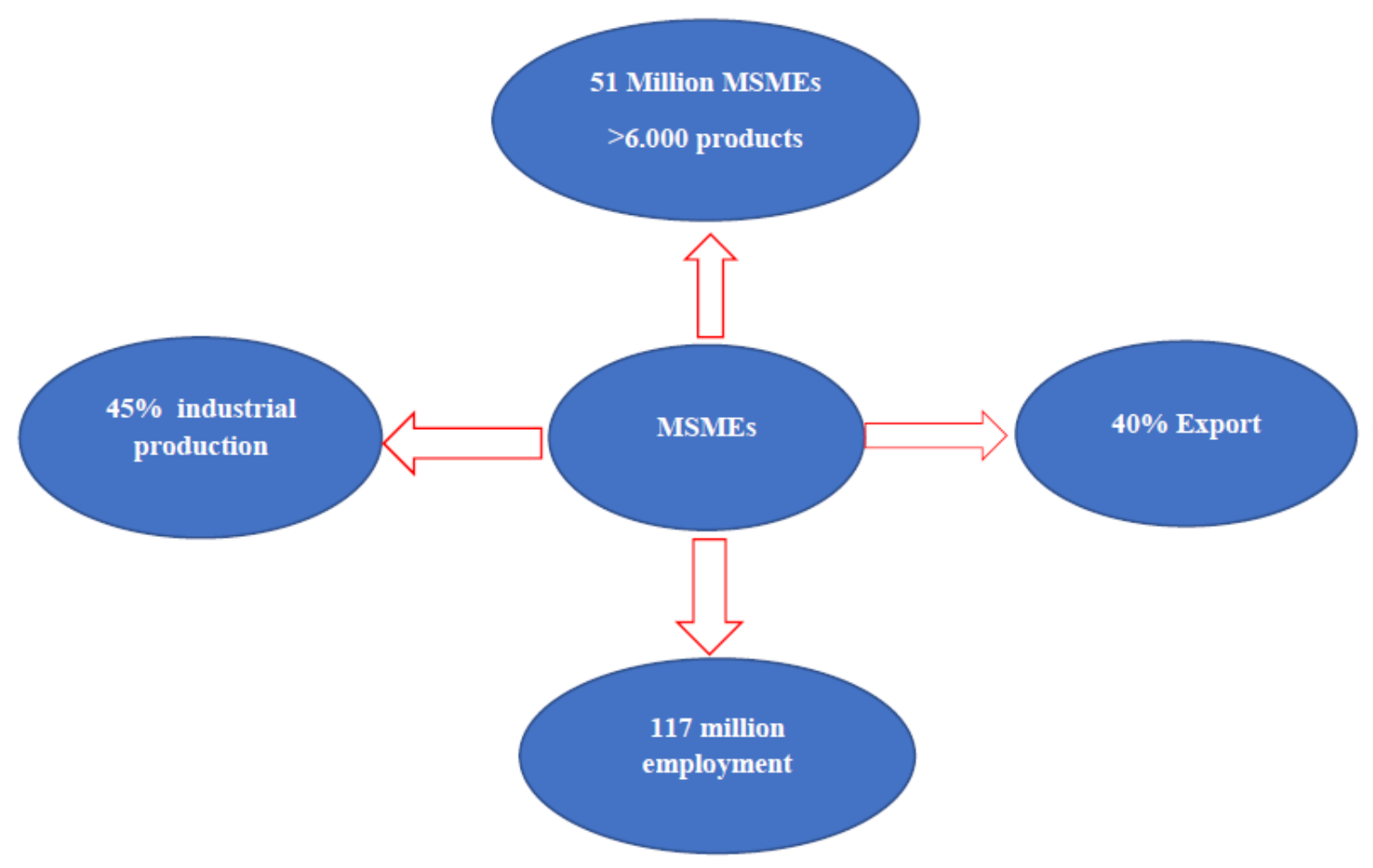

Figure 1. Micro, Small and Medium Enterprises (MSMEs) in India (2015-16)

Source: UNIDO (2017)

According Bagale (2014), SMEs and India's micro-enterprises can increase productivity, provide products and services to millions of customers through $\mathrm{B} 2 \mathrm{~B}$, Business to Consumer (B2C) and Business to Government (B2G) by applying e-commerce and the digital economy. E-commerce is growing rapidly in India, the e-commerce industry is worth $\$ 5.4$ billion by 2011 and estimated at $\$ 31$ billion by 2016 (Industrial, Working, \& Series, 2017). In addition, e-commerce reports show that $85 \%$ of SMEs use e-commerce as an effective tool to increase sales; $73 \%$ of SMEs said that e-commerce helps enterprises to better understand and expand the market; and $60 \%$ to $80 \%$ of SMEs think that e-commerce can reduce marketing and sales costs (Industrial et al., 2017; Min of MSME - Govt of India, 2016; KPMG, 2016). All results show that e-commerce plays an essential role in contributing to SMEs development in particular and the economy of India in general. In addition, the B2C e-commerce segment plays an important role in e-commerce and the economy. For example, in India, there are a number of leading and large companies in the B2C ecommerce model such as Amazon.com, Flipkart.com, Snapdeal.com, bigbasket.com, uber.com, olacabs.com and so on. The e-commerce industry has contributed to the India's economy with a total value of $\$ 16$ billion for the B2C segment by 2015 (contributing 1\% of GDP) and is expected to reach $\$ 100$ billion by 2020 (UNIDO, 2017). This shows that e-commerce not only promotes the SMEs development but also promotes economic growth in India.

Although e-commerce brings many benefits for SMEs, but in the process of applying electronic commerce SMEs also face many barriers. Chitura et al. (2008) mentioned e-commerce barriers in SMEs as follows: lack of technology awareness, lack of business 
opportunities, concerns about e-commerce security / payment systems, infrastructure issues, uncertainties about the benefits and advantages of e-commerce, lack of technical skill and IT knowledge among employees, inadequate legal systems, lack of software solutions E-commerce for SMEs, lack of suitable online payment system, lack of strategic vision, etc.

For SMEs in India, research by Poorja Sharma (2014) shows that staff readiness to access and use a new system is the biggest barrier to e-commerce adoption. This study also shows that the levels of education, lack of knowledge about the benefits of e-commerce are also reasons for preventing SMEs from applying e-commerce. In addition, the low level of users and the small number of suppliers are also obstacles of e-commerce application by SMEs.

Achieving e-commerce achievements and development for India's SMEs is due to various factors. Firstly, the main driver of India's e-commerce growth is the boom of internet, mobile devices (Morgan and Stanley, 2016, UNIDO, 2017). This leads to a rapidly growing number of online stores. There are about 50 million online stores by 2015, it is estimated that by 2020 there will be about 320 million (Sonia Mukherjee, 2017). In addition, India is one of the fastest growing economies in the world and with higher incomes has made India as one of the fastest growing consumer markets in the world. Increasing income, lifestyle changes, living standards and living standards have spurred the e-commerce industry in India.

Second, more and more SMEs use e-commerce to provide products and merchandise ranging from fresh flowers, consumer goods, cosmetics, movie tickets, housewares, etc. This helps customers when shopping with e-commerce has many options like shopping at traditional markets, supermarkets, shops.

Third, the development of technology such as 3G, 4G and mobile devices; especially technological innovation towards convenience, has led to an increase in the number of users of services $3 \mathrm{G}, 4 \mathrm{G}$, online shoppers. Online shoppers can access e-commerce websites conveniently and conveniently on their mobile devices. This is reflected in the development of e-commerce in general and e-commerce for SMEs effectively, it requires that the country has a good technology background and infrastructure (internet infrastructure, payment infrastructure, logistics, etc.). Other notable factors include demographics (young populations, rising living standards, rising middle classes, etc.), and the explosion of social media platforms. This leads to the further development of the e-commerce market (UNIDO, 2017).

In addition, the government plays a very important role, contributing successfully to the application of e-commerce to SMEs in India. The government has made some initiatives to promote the e-commerce industry in India. The government has taken advantage of digital e-commerce to organize traditional offline markets, even for agricultural products. The government has taken advantage of digital e-commerce to organize traditional offline markets, even for agricultural products. The government has put up an electronic market platform to connect farmers with different agricultural markets to sell agricultural commodities online. Top government initiatives such as "Digital India", "Start-up India", "Make in India" và "Skill India" contributing to the development of e-commerce. In addition, the government is actively attracting FDI into e-commerce to promote the development of the industry. In March 2017, the government allowed $100 \%$ of FDI to invest in online retail and attracted 
more foreign investment in the sector.

To support and promote the development of the e-commerce industry, the Indian government implemented a major tax reform by introducing goods and services tax (GST). GST will implement a single comprehensive indirect tax regime that will apply across all states for the provision of goods and services. Implementation of GST is expected to include all types of taxes, such as excise taxes, service taxes and customs duties, VAT, entry taxes, etc. at the state level. GST will enhance the efficiency of the e-commerce industry in a number of ways, including transparency and simplification of taxation in India and the elimination of double taxation and improved supply chain efficiency.

The policies, activities of the government, associations, e-commerce businesses focus on supporting SMEs overcome barriers in the application of e-commerce. The government supports SMEs use e-commerce by setting up a system of technology centers to transfer technology to SMEs, and at the same time support the training for SMEs to understand clearly e-commerce. E-commerce businesses provide financial support programs, reducing transaction costs on their e-commerce platforms; support SMEs in brand building, marketing products; or they cooperate with many organizations and research institutes to support skills for SMEs.

\section{Conclusions}

This paper provides an understanding about the adoption of e-commerce by SMEs in India which is one of the leading countries in e-commerce. The results of this study indicate that the successful application of e-commerce to Indian SMEs for various reasons, in which government plays an important role. By studying e-commerce application for SMEs in India, it will draw lessons for countries in the world, especially developing countries.

\section{Acknowledgments}

This research is funded by Vietnam National Foundation for Science and Technology Development (NAFOSTED) under grant number 502.01-2019.15

\section{References}

Al-Kibsi, G., de Boer, K., Mourshed, M., \& Rea, N. P. (2001). Putting citizens on-line, not in line. McKinsey Quarterly, 2, 65-73.

Almousa, M. (2013). Barriers to E-Commerce Adoption: Consumers' Perspectives from a Developing Countries. iBusiness, 5(2), 65-71. https://doi.org/10.4236/ib.2013.52008

Arendt, L. (2008). Barriers to ICT adoption in SMEs: how to bridge the digital divide?. Journal of Systems and Information Technology, 10(2), 93-108.

https://doi.org/10.1108/13287260810897738

Bagale, G. S. (2014). Determinants of E-Commerce in Indian MSME Sector: A Conceptual Research Model Based on TOE Framework. Universal Journal of Management, 2(3), 105-115. https://doi.org/10.13189/ujm.2014.020301 


\section{Macrothink}

Business and Economic Research ISSN 2162-4860 2019, Vol. 9, No. 3

Brem, A. (2008). The Boundaries of Innovation and Entrepreneurship - Conceptual Background and Selected Theoretical and Empirical Aspects, Gabler, Wiesbaden.

Chitura, T., Mupemhi, S., Dube, T., \& Bolongkikit, J. (2008). Barriers to Electronic Commerce Adoption in Small and Medium Enterprises: A Critical Literature Review. Journal of Internet Banking and Commerce, 13(2), 1-13.

Chugh, A. (n.d.). What is the future trend of e -learning in India. [Online] Available: https://www.quora.com/What-is-future-of-E-learning-in-India

Chunlin, S. K. W. H. L. S. Z. X. Z. J. W. S. Z. B. Z. (n.d.). E-commerce development report of the SMEs of BRICS countries.

Cohen, S., \& Kallirroi, G. (2006). E-commerce Investments from an SME perspective: Costs, Benefits and Processes. Journal of Information Systems Evaluation, 9(2), 45-56.

Franco, C. E., \& Bulomine, R. S. (2016). Advantages And Challenges Of E-commerce Customers And Businesses: In Indian Perspective. International Journal of Research Granthaalayah, 4(3), 7. [Online] Available:

http://granthaalayah.com/Articles/Vol4Iss3/02_IJRG16_SE03_02.pdf

Freeman, E. Q. (2001). B2B's Operational and Risk Implications. Financial Executive, 17(3), B14-B16.

Gibbs, J. L., \& Kraemer, K. L. (2004). A Cross-Country Investigation of the Determinants of Scope of E-commerce Use: An Institutional Approach. Electronic Markets, 14(2), 124-137. https://doi.org/10.1080/10196780410001675077

Girish, S. B. (2014). Determinants of E-Commerce in Indian MSME Sector: A Conceptual Research Model Based on TOE Framework. Universal Journal of Management, 2(3), 105-115.

Holley, C., \& Hunton, J. E. (1996). Doing Business on the Internet. Journal of Accountancy, 181(3), 42-48. https://doi.org/10.1007/978-1-4471-0561-9

Huang. (2007). Entry to the E-Commerce Markets of China and Taiwan: An Application of Content Analysis. International Journal of Management, 24(1), 82-92.

Huu Phuoc Dai Nguyen, \& Thai Binh Dang. (2017). The Impact of e-Commerce in Vietnamese SMEs. European Journal of Business Science and Technology, 3(2), 90-95. https://doi.org/10.11118/ejobsat.v3i2.106

Industrial, S., Working, D., \& Series, P. (2017). National Report on E-commerce Development in India.

Kapurubandara, M., \& Lawson, R. (2006). Barriers to Adopting ICT and e-commerce with SMEs in Developing Countries: An Exploratory study in Sri Lanka. Proceedings of the 2006 Collector Conference on Electronic Commerce (CollECTeR '06), Adelaide, Australia.

Kaynak, E., Tatoglu, E., \& Kula, V. (2005). An analysis of the factors affecting the adoption 
of electronic commerce by SMEs: Evidence from an emerging market. International Marketing Review, 22(6), 623-640. https://doi.org/10.1108/02651330510630258

Kshetri, N. (2007). Barriers to e-commerce and competitive business models in developing countries: A case study. Electronic Commerce Research and Applications, 7, 443-452. https://doi.org/10.1016/j.elerap.2007.02.004

Mayer-Guell, A. M. (2001). Business-to-Business Electronic Commerce. Management Communication Quarterly, 14(4), 644-652. https://doi.org/10.1177/0893318901144008

Meglena, K. (2009). Barriers to eCommerce in the EU. [Online] Available:

http://europa.eu/rapid/press-release_SPEECH-09-91_en.pdf

Min of MSME - Govt of India. (2016). MSME- Annual Report 2015-16. MSME- Annual Report 2015-16, 53(9), 1689-1699. https://doi.org/10.1017/CBO9781107415324.004

Mitra, S., \& Chaya, A. (1996). Analyzing Cost-Effectiveness of Organizations: The Impact of Information Technology Spending. Journal of Management Information Systems, 13(2), 29-57. https://doi.org/10.1080/07421222.1996.11518122

Niranjanamurthy, M., \& Chahar, D. (2013). The study of E-Commerce Security Issues and Solutions. International Journal of Advanced Research in Computer and Communication Engineering, 2(7), 1-12.

Oye, D., Mazleena, S., \& Noorminshah, I. (2012). The Impact of E-Learning in Workplace_ Focus on Organizations and Healthcare Environments.pdf. International Arab Journal of E-Technology.

Pooja, S. (2014). Barriers to Adopting E-business in SMEs in India: An Exploratory Study. International Journal of Business Management and Economics Research, 1(1), 13-26.

Radstaak, B. G., \& Ketelaar, M. H., \& Hastings, P. H. I. D. C. (1998). Worldwide logistics: the future of supply chain services. Holland International Distribution Council, The Hague.

Rahayu, R., \& Day, J. (2015). Determinant Factors of E-commerce Adoption by SMEs in Developing Country: Evidence from Indonesia. Procedia - Social and Behavioral Sciences, 195(1), 142-150. https://doi.org/http://dx.doi.org/10.1016/j.sbspro.2015.06.423

Rosemary, S., \& Standing, C. (2004). Benefits and Barriers of Electronic Marketplace Participation: An SME Perspective. Journal of Enterprise Information Management, 17(4), 301-311. https://doi.org/10.1108/17410390410548715

Sairamesh, J., Mohan, R., Kumar, M., Hasson, T., \& Bender, C. (2002). A Platform for Business-to-Business Sell-Side, Priate Exchanges and Marketplaces. IBM Systems Journal, 41(2), 242-252. https://doi.org/10.1147/sj.412.0242

Sonia, N. (2017). E-Commerce and SMEs: A Case study of India. International Journal of Commerce, Business and Management (IJCBM), ISSN: 2319-2828.

Sultana, R., Lopez, J. L., \& Rusu, L. (2011). Barriers to e-Commerce Implementation in 


\section{Macrothink}

Business and Economic Research

ISSN 2162-4860 2019, Vol. 9, No. 3

Small Enterprises in Sweden. In: Cruz-Cunha M. M., Varajão J., Powell P., Martinho R. (Eds.), ENTERprise Information Systems. CENTERIS 2011. Communications in Computer and Information Science, vol 219. Springer, Berlin, Heidelberg.

https://doi.org/10.1007/978-3-642-24358-5_18

Tornatzky, L. G., \& Fleischer, M. (1990). The processes of technological innovation. Lexington, MA: Lexington Book.

UNIDO. (2018). E-commerce development report of the SMEs of BRICS countries.

Van Huy, L., Rowe, F., Truex, D., \& Huynh, M. Q. (2012). An Empirical Study of Determinants of E-Commerce Adoption in SMEs in Vietnam. Journal of Global Information Management, 20(3), 23-54. https://doi.org/10.4018/jgim.2012070102

Verdoy, A. (2018). New tech tools drive SME success in E-commerce. [Online] Available: https://www.digitaldoughnut.com/articles/2018/june/new-tech-tools-drive-sme-success-in-b2 c-e-commerce

Walczuch, R., Van Braven, G., \& Lundgren, H. (2000). Internet Adoption Barriers for Small Firms in the Netherlands. European Management Journal, 18(5), 561-572. https://doi.org/10.1016/S0263-2373(00)00045-1

Zhu, K., \& Kraemer, K. L. (2002). E-commerce metrics for net-enhanced organizations: assessing the value of e-commerce to firm performance in the manufacturing sector. Information System Research, 13(3), 275-295. https://doi.org/10.1287/isre.13.3.275.82

\section{Copyright Disclaimer}

Copyright for this article is retained by the author(s), with first publication rights granted to the journal.

This is an open-access article distributed under the terms and conditions of the Creative Commons Attribution license (http://creativecommons.org/licenses/by/3.0/). 